\title{
Prescription errors in a primary care university unit: urgency of pharmaceutical care in Mexico
}

\author{
Miriam Zavaleta-Bustos ${ }^{1}$, Lucila Isabel Castro-Pastrana*,1, Ivette Reyes-Hernández², \\ Maria Argelia López-Luna', Isis Beatriz Bermúdez-Camps²
}

'Departamento de Ciencias Químico-Biológicas, Universidad de las Américas Puebla, ${ }^{2}$ Facultad de Ciencias Naturales, Universidad de Oriente, Santiago de Cuba

*Correspondence:

L. I. C. Pastrana

Departamento de Ciencias Químico Biológicas

Universidad de las Américas Puebla Exhacienda de Sta Catarina Mártir sin número

C.P. 72820 San Andrés Cholula -

Puebla, México

E-mail: lucila.castro@udlap.mx

castro lucila@hotmail.com
The purpose of this study was to assess prescription rationality and most common prescription errors at the primary care clinic of a Mexican university.A retrospective drug utilization review of indication-prescription type was carried out. A random sample of 370 medical records of patients assisted over a year period, were reviewed. Prescription appropriateness was evaluated according to the variables: indication, dosage regimen, administration route, contraindications, interactions, medication duplicity, unnecessary or missing medications. Prescriptions were rated as appropriate (no prescription errors found) or inappropriate (at least one prescription error found). The benefit-risk ratio was calculated for each prescription. This study revealed a $58 \%$ of inappropriate prescriptions in the Mexican primary care university clinic, mostly due to errors on dosage regimen and innapropiate drug selection. As a result of $\chi^{2}$ analysis, it was found that the pharmacotherapeutic variables chosen for the prescription assessment in this study, were determinant in prescription appropriateness rating. Nimesulide, ciprofloxacin, ranitidine, ketorolac and paracetamol were the most prescribed drugs as well as the most common cause of errors found. The prescription error rate revealed by this study addresses the need for strategies to improve prescription's quality. Introducing pharmacists as a key part of health care team is a mean proposed to prevent medication errors and to solve the urgency of pharmaceutical care implementation in all primary care facilities in Mexico.
Uniterms

- Drugs/utilization study

- Drugs/rational use

- Drugs/prescription errors

- Pharmaceutical care

\section{INTRODUCTION}

Nowadays, more than seven thousand registered pharmaceutical products are commercialized in Mexico and each year around 600 new products are introduced to the Mexican market (Secretaría de Salud de México, 2005). This situation confronts Mexican general practitioners at the primary care level, to a wide range of 
available medicines, conducting to a complex decision making process in therapeutics.

Moreover, although the World Health Organization (WHO) recommended since 1988 the inclusion of pharmacists on the health care teams (Organización Panamericana de la Salud, 1993), pharmacists have not yet been completely recognized and accepted by the Mexican health system as the health care professionals responsible for promoting the correct use of medicines. There is still no drug use monitoring in all Mexican health institutions, not enough drug information centers (only six distributed in all the country) and there are very few pharmacists collaborating with other health care professionals in hospitals and in Drug and Therapeutics Committees. Thus, research on rational-drug-use in Mexico, identification of the most frequent medication errors in public and private health care facilities and implementation of strategies for solving and preventing drug misadventures with full participation of pharmacists, are actions still far away to be routinely carried out.

WHO recently stated, that the irrational use of drugs is increasing; one of the reasons is that medication use is worse in the private health sector of underdeveloped countries than in the public sector; in fact, the private sector has become more active than the public sector increasing its participation in health assistance around the world (World Health Organization, 2006). The present study is the first pharmacoepidemiological study published where drug utilization is assessed in a private Mexican primary care facility.

The National Coordinating Council for Medication Error Reporting and Prevention (NCCMERP) defined a medication error as "any preventable event that may cause or lead to inappropriate medication use or patient harm while the medication is in the control of the health care professional, patient, or consumer. Such events may be related to professional practice, health care products, procedures, and systems, including prescribing; order communication; product labeling, packaging, and nomenclature; compounding; dispensing; distribution; administration; education; monitoring; and use" (NCCMERP, 2007).

The rational use of drugs begins with a correct prescription; nevertheless, according to the consulted literature, this stage is where more than $50 \%$ of all treatments present errors (Otero et al., 1992; Tamblyn et al., 2003; González et al., 2005). Some of the most important situations that should be considered as prescription errors are: a) errors during the decision making process (drug not indicated, contraindicated drug, drug to which the patient has a documented allergy or a significant risk of presenting adverse reactions, drug-disease interactions, drug-drug interactions, inappropriate drug for age or clinical condition, medication duplicity, unnecessary drugs, inappropriate dosage, dosage form, administration route, concentration or frequency of administration); and b) errors in prescription writing that may or may not affect the patient (illegible, unclear or potentially error causing written prescriptions, omissions, transcription errors) (Otero et al., 1992; Tamblyn et al., 2003; ASHP, 1993; Dean et al., 2000). In primary health care facilities, most of these medication misadventures can only be classified as potential errors, because there is little information whether they actually reach the patient or not.

There is a lack of publications about the type and frequency of occurrence of medication errors in primary care. Medication error research at this level is limited mostly because users of such services are not inpatients as occurs in hospitals, also due to the elevated assistential pressure (time, patient/physician, and consultation-time/ patient rates, among other reasons) and to the primary care practitioners who are misinformed on events considered as prescription errors (Generalitat de Catalunya, 2004).

Pharmacoepidemiologic studies are useful diagnostic tools for identifying needs in quality improvement for health services and in drug prescription. They are intended to justify development of strategies and implementation of health programs that may help correct deficient aspects found throughout those studies (Hernández et al., 2000). In 1988 , WHO found a low distribution of pharmacists in underdeveloped countries and recommended those countries to start research protocols at hospital and community pharmacies in order to promote rational drug use (Organización Panamericana de la Salud, 1993; Bakker, 1996). Although some efforts have been already done in Mexico and pharmacoepidemiologic studies have been conducted in hospitals of some federal states like Hidalgo (González, Viso, 2001; Viso et al., 2003; LópezSánchez et al., 2001; Montaño, Viso, 2000), there is still a low probability of finding a pharmacist at any hospital, health care facility or community pharmacy.

The present study has been conducted at the primary care facility of UDLA university campus, in the state of Puebla, Mexico. At this health care unit, approximately 10.000 medical consultations are given each year, free of charge to students, academic and administrative staff as well as direct relatives of them.

Although since year 2000 there is pharmacy undergraduate program at this university, no prior initiatives have been made to introduce UDLA pharmacy students to professional practices before; by detecting, solving, monitoring and preventing medication errors at the 
university primary care unit, and actively promoting at the same time in Mexico, the role of pharmacists as health care providers.

The aim of this study was to detect the most frequent prescription errors in this facility, through an indicationprescription pharmacoepidemiologic methodology, in order to justify the implementation of pharmaceutical care services at the institution as well as the inclusion of pharmacists as part of the health care team.

\section{METHODS}

A retrospective drug use review of indicationprescription type (Figueiras et al., 2000) was carried out at a primary care university unit. 370 medical records were randomly chosen ("RANDOM") function, Microsoft Office Excel 2003) and reviewed as a sample (95\% confidence level) of the total of medical consultations ( $\mathrm{n}=$ 9.874 prescriptions) attended from January to December 2004. Only complete records of adult male and female patients ( $>17$ years-old) were included in this study. Confidentiality of patients' identities were kept by assigning an identification code to each medical record.

Data on patient demographics, indication for each medication, dosage, dosage form, regimen and concurrent medications were collected. Data on duration of medication was not reported in the prescriptions and could not be evaluated.

Appropriateness of prescription was evaluated according to the following pharmacotherapeutic variables: indication, dosage regimen (dose and frequency), administration route, contraindications, potential interactions, medication duplicity, unnecessary or missing medications. These variables were chosen after consensing several rational drug use and medication error definitions (WHO, 2006; Dean et al., 2000; Cobaugh, Krenzelok, 2006). Judgements of appropriateness were established by comparing the therapy given with primary, secondary and tertiary bibliographic sources containing objective, accurate, reliable and unbiased drug information and pharmacotherapeutic guidelines (Dipiro et al., 2005; McEvoy, 2006a; Randall, Neil, 2004; McEvoy, 2006b).

Prescriptions were rated as "appropriate" when no errors were found according to pharmacotherapeutic variables. "Inappropriate" prescriptions contained at least one error for any of the variables assessed.

Non-parametric chi square tests of independence were used to analyze the evaluated variables and the appropriateness of prescriptions with a confidence level of $95 \%$ and a significance level of $\mathrm{p}<0.05$ (Statgraphic 5.1 for Windows 2001).
Since our study was retrospective, we were not able to do interventions to correct prescription errors found and it was impossible to know if "inappropriated" prescriptions caused harm to the patient because medical records did not contain information about it.

The benefit-risk ratio was calculated for each prescription according to equation 1.1 , adapted from criteria used by Lyle et al. and Ramos et al. (Lyle et al., 1979; Ramos et al., 2003).

equation 1.1:

benefit-risk ratio $=(\mathrm{B} 1+\mathrm{B} 2+\mathrm{B} 3) /(\mathrm{R} 1+\mathrm{R} 2+\mathrm{R} 3)$

To quantify this ratio, a score for each indicator (benefit and risk) was established (s. Table I).

A benefit-risk ratio $<1$ pointed out prescriptions where pharmacotherapy decisions were more risky than beneficial for the patients' clinical condition. A benefit-risk ratio $>1$ was obtained for prescriptions where pharmacotherapy choices were more beneficial than risky. Prescriptions with a benefit-risk ratio equal to 1 had the same probability to benefit than to harm the patient.

The benefit-risk ratio was obtained for each medication and an average of all ratios was calculated. The total of prescriptions with a ratio $>1$ and $<1$ were calculated.

\section{RESULTS}

A sample of 370 prescriptions was evaluated; $60 \%$ of the patients of the sample were female and $40 \%$ were male. Mean \pm SD age was $26 \pm 11$ years old and $73 \%$ of the patients were between 17-26 years old. The most frequent diagnoses were: diseases of respiratory system (30.5\%); injury, poisoning and certain other consequences of external causes (11.7\%); and diseases of the digestive system (11.4\%) (s. Table II).

At least 2 drugs were prescribed to $64 \%$ of the patients, with a mean \pm SD of $1.9 \pm 0.9$ drugs per patient. For the 394 different health problems diagnosed to the patients of the sample, a total of 722 medications (280 different drugs) were prescribed, and only 20 of them (7.1\%) were prescribed by its generic name.

$75 \%$ of the drugs prescribed belong to $\mathrm{M}, \mathrm{J}, \mathrm{R}$ and $\mathrm{A}$ groups of the Anatomical-Therapeutic-Chemical Classification (ATC) (s. Table III). Most prescribed drug were: nimesulide ( $25 \%$ of total prescriptions), followed by ciprofloxacin $(9.5 \%)$ and ranitidine (9.5\%) (s. Table IV).

Due to the retrospective nature of this study, all identified medication errors belonged to the category of prescription errors. $214(58 \%)$ of the sample of 370 
TABLE I - Benefit/Risk ratio assessment of the prescriptions

\section{Indicators related to pharmacotherapeutic benefit of the prescription}

Benefit $1\left(B_{1}\right)$

Appropriateness of the prescription according to the indication

20 points: If drug was of first choice for the indication

10 points: If drug was not of first choice for the indication

5 points: If drug is not indicated

\section{Benefit $2\left(B_{2}\right)$}

Dosage regimen
Benefit 3 (B3)

Presence of beneficial drug interactions in the prescription

20 points: More than two beneficial drug interactions

10 points: One to two beneficial drug interactions

5 points: No beneficial drug interactions

\section{Indicators related to pharmacotherapeutic risk in the prescription}

\begin{tabular}{lll}
\hline $\begin{array}{l}\text { Risk 1 }\left(\mathbf{R}_{\mathbf{1}}\right) \\
\text { Drug interaction risk in the } \\
\text { prescriptions }\end{array}$ & $\begin{array}{l}\text { Risk } \mathbf{2}\left(\mathbf{R}_{\mathbf{2}}\right) \\
\text { Medication duplicity }\end{array}$ & $\begin{array}{l}\text { Risk }\left(\mathbf{R}_{\mathbf{3}}\right) \\
\text { Unnecessary medications }\end{array}$ \\
\hline $\mathbf{2 0}$ points: More than 2 risky & $\mathbf{2 0}$ points: More than two drugs & $\mathbf{2 0}$ points: More than one medication \\
drug interactions & were prescribed for the same & was unnecessary \\
$\mathbf{1 0}$ points: One to two risky & $\begin{array}{l}\text { indication and only one of } \\
\text { them was necessary }\end{array}$ & $\begin{array}{l}\mathbf{1 0} \text { points: One medication was } \\
\text { unnecessary }\end{array}$ \\
$\mathbf{5}$ points: No risky drug interactions & $\begin{array}{l}\mathbf{1 0} \text { points: Two drugs were } \\
\text { prescribed for the same indication }\end{array}$ & $\begin{array}{l}\mathbf{5} \text { points: No unnecessary medications } \\
\text { found }\end{array}$ \\
& $\begin{array}{l}\text { and only one of them was necessary } \\
\mathbf{5} \text { points: No medication duplicity }\end{array}$ \\
\hline
\end{tabular}

TABLE II - Most frequent diagnoses for the patients of the sample $(\mathrm{n}=370) . * \mathrm{ICD}=$ International Classification of Diseases by World Health Organization

\begin{tabular}{llc}
\hline ICD code & Chapter & $\begin{array}{c}\text { Number of patients } \\
\mathrm{n}(\%)\end{array}$ \\
\hline J00- J99 & Diseases of the respiratory system & $120(30.5)$ \\
S00-T99 & Injury, poisoning and certain other consequences of external causes & $46(11.7)$ \\
K00-K93 & Diseases of the digestive system & $45(11.4)$ \\
A00-A09 & Intestinal infectious diseases & $35(8.9)$ \\
M00-M99 & Diseases of the musculoskeletal system and connective tissue & $32(8.1)$ \\
N00-N99 & Diseases of the genitourinary system & $24(6.1)$ \\
H00-H59 & Diseases of the eye and adnexa & $15(3.8)$ \\
L00-L99 & Diseases of the skin and subcutaneous tissue & $13(3.3)$ \\
R00-R99 & Symptoms, signs and abnormal clinical and laboratory findings, not elsewhere classified & $13(3.3)$ \\
G00-G99 & Diseases of the nervous system & $10(2.5)$ \\
\hline
\end{tabular}

prescriptions were rated as "inappropriate" with a mean \pm SD of $1.3 \pm 0.6$ errors per each inappropriate prescription. In total, 268 prescription errors were found. As a result of $\chi^{2}$ analysis, it was found that the pharmacotherapeutic variables chosen for the prescription assessment in this study were determinant in prescription appropriateness rating, demonstrating also that the assessed variables were correctly selected (s. Table V).

92 prescriptions were rated as "inappropriate" because of discrepancies in indication and $78 \%$ of them were rated so because of use of second-line drugs or drugs not indicated for the patient's clinical condition. 
TABLE III - Most frequently prescribed therapeutic groups according to first level of ATC Classification by WHO Collaborating Centre for Drug Statistics Methodology

\begin{tabular}{lcc}
\hline & First level of ATC Classification & $\begin{array}{c}\text { Number of patients } \\
\mathrm{n}(\%)\end{array}$ \\
\hline $\mathrm{M}$ & Muscle-Skeletal System & $203(28.1)$ \\
$\mathrm{J}$ & Antiinfectives for Systemic Use & $116(16.0)$ \\
$\mathrm{R}$ & Respiratory System & $114(15.8)$ \\
$\mathrm{A}$ & Alimentary Tract and Metabolism & $110(15.2)$ \\
$\mathrm{N}$ & Nervous System & $50(6.9)$ \\
$\mathrm{D}$ & Dermatologicals & $31(4.3)$ \\
$\mathrm{G}$ & Genito-Urinary System and Sex Hormones & $21(2.9)$ \\
$\mathrm{H}$ & Systemic Hormonal Preparations, excl. Sex Hormones and Insulins & $10(1.4)$ \\
$\mathrm{S}$ & Sensory Organs & $9(1.2)$ \\
$\mathrm{C}$ & Cardiovascular System & $6(0.8)$ \\
$\mathrm{B}$ & Blood and Blood Forming Organs & $5(0.7)$ \\
$\mathrm{P}$ & Antiparasitic Products, Insecticides and Repellents & $4(0.6)$ \\
& Not classified & $43(6.0)$ \\
\hline
\end{tabular}

TABLE IV - Most prescribed drugs according to fourth level of ATC classification by WHO Collaborating Centre for Drug Statistics Methodology

\begin{tabular}{llcc}
\hline ATC code & Drug & Administration Route & $\begin{array}{c}\text { Number of Patients } \\
\mathrm{n}(\%)\end{array}$ \\
\hline M01AX17 & Nimesulide & Oral & $47(24.9)$ \\
J01MA02 & Ciprofloxacin & Oral & $18(9.5)$ \\
A02BA02 & Ranitidine & Oral & $18(9.5)$ \\
M01AB15 & Ketorolac & Oral & $16(8.5)$ \\
M01AE53 & Paracetamol / Ketoprofen & Oral & $14(7.4)$ \\
J01CA04 & Amoxicillin & Oral & $12(6.3)$ \\
M01AB15 & Ketorolac & Parenteral & $12(6.3)$ \\
& Lactobacillus Boucardii strain & Oral & $12(6.3)$ \\
N02BE01 & Paracetamol & Oral & $12(6.3)$ \\
A03AA05 & Trimebutine & Oral & $12(6.3)$ \\
\hline
\end{tabular}

One example, was the prescription of telithromycin (J01FA15) for the empirical treatment of pharyngitis (J00 y J02.9) without justification, because there were no microbiologic studies showing that the infection was caused by macrolid resistant bacteria and there was no information on the patient's medical record of being allergic to betalactamic antibiotics. For other inappropriate prescriptions because of incorrect indication, antibiotics (trimethoprim/sulfamethoxazole J01EE01), proton-pump inhibitors (lansoprazole A02BC03 and pantoprazole $\mathrm{A} 02 \mathrm{BC} 02$ ) and $\mathrm{H} 2$ antagonists (ranitidine A02BA02) were incorrectly prescribed to patients with a diagnosis of colitis (K52.9). Another example was the prescription of cefalexine (J01DB01) to a patient whose medical record mentioned being allergic to penicillin (J01CE01), and in fact, the patient presented an allergic reaction reported a few days later on the next visit's record.

Of the 102 prescriptions rated as inappropriate because of the variable dosage regimen, $66 \%$ had longer dosage interval and $29 \%$ shorter dosage interval than recommended, $6 \%$ had a supratherapeutic dose and $13 \%$ a subtherapeutic dose. For example, nimesulide (M01AX17) was incorrectly prescribed 15 times, because tablets of 100 mg were ordered in 8-hour or 24-hour dosing intervals instead of in 12-hour dosing intervals as recommended.

$6.5 \%$ of assessed prescriptions were rated as 
TABLE V - Prescription appropriateness according to the pharmacotherapeutic variables assessed. $\chi^{2}=1144.38$; freedom degrees $=6 ; \mathrm{p}<0.05 ; \mathrm{n}=370$

\begin{tabular}{lcccc}
\hline & \multicolumn{3}{c}{ Prescriptions } \\
\cline { 2 - 5 } Pharmacotherapeutic & \multicolumn{2}{c}{ Appropriate } & \multicolumn{2}{c}{ Inappropriate } \\
Variables & No. & $\%$ & No. & $\%$ \\
\hline Indication & 278 & 75.1 & 92 & 24.9 \\
Dosage regimen (dose and frequency) & 268 & 72.4 & 102 & 27.6 \\
Unnecesary medications & 346 & 93.5 & 24 & 6.5 \\
Medication Duplicity & 356 & 96.2 & 14 & 3.8 \\
Potential drug-drug interactions & 347 & 95.9 & 23 & 6.2 \\
Missing medications & 362 & 97.8 & 8 & 2.2 \\
Administration route & 365 & 98.6 & 5 & 1.3 \\
\hline Total & 156 & 42.2 & 214 & 57.8 \\
\hline
\end{tabular}

inappropriate for unnecessary medications and $2.2 \%$ for missing medications, according to the patient's diagnosis. One example of this, was the concomitant prescription of valdecoxib (M01AH03), parecoxib (M01AH04) and the diclofenac/misoprostol combination (M01AB55) for lumbalgia (M54.9). In other cases, analgesics and antipiretic drugs were missing when considered necessary.

In $3.8 \%$ of the prescriptions, the medication discrepancies were categorized as medication duplicities, where at least one of the drugs was repeated in the same prescription. Paracetamol (N02BE01) was the most duplicated drug, mainly in prescriptions for patients with respiratory diseases, because it is one of the most common active ingredients of several fever and cold and cough medicines.

Potential drug-drug interactions were detected in $6.2 \%$ of all prescriptions. The most frequent interaction (14 prescriptions) was the concurrent prescription of ketoprofen (M01AE03) with paracetamol (N02BE01), followed by the concomitant prescription (in 3 cases) of antacids (A02A) with ranitidine (A02BA02).

The pharmacotherapeutic variable with the lowest frequency of error was administration route, with only 5 prescriptions categorized as inappropriate.

$93.5 \%$ of the prescriptions showed a calculated benefit/risk ratio greater than 1 . The mean value of the benefit/risk ratios of all assessed prescriptions was 2.5.

Non-steroidal anti-inflammatory drugs (NSAIDs) and ranitidine were the drugs most frequently involved in the prescriptions with a benefit/risk ratio smaller than 1 , mainly because of duplicity and unnecessary prescription.

All prescribing errors found were category B errors according to the NCCMERP Index for Categorizing Medication Errors Algorithm (NCCMERP, 2007), because the retrospective character of this study prevented the possibility of knowing if the errors reached the patient or not, whether we did not know if the patient took the medication exactly as it was ordered.

\section{DISCUSSION}

Our study reports that $58 \%$ of the analyzed primary care medical records had at least one prescription error, supporting previous findings of other authors (Marcellino, Kelly, 2001). Our results are also similar to Kelly's review at drug-adverse-reaction reports published by Clin-Alert from 1976 to 1995, where he found that a significant number of medication errors were produced during the prescription writing process, and the prescription of a second-line drug for the patient's indication as well as prescribing an incorrect dosage, were the most observed errors (Kelly, 2001). Kelly concluded that most fatal adverse events could be preventable by physicians, nurses or pharmacists in hospitals or primary care units by having computational systems which could track potential and actual medication errors to prevent or solve them, and by having more pharmacists monitoring prescriptions and taking care of patients (Kelly, 2001). Moreover, we conclude that besides electronic prescribing systems and the development of national policies to include pharmacists in the health care team, Mexico needs also urgently drug information and toxicological information centers, at least one in each federal state, for improving rational drug use and for doing surveillance of drug adverse reactions and medication misadventures.

Dean et al. (2000) pointed out that a major problem with interpreting quantitative prescribing error studies is that the definition of an error used by the researchers is 
often ambiguous or not given at all, making comparisons of error rates across the literature, hard to do. Taking their research results into consideration, we defined explicitly in our study, the pharmacotherapeutic variables assessed for the identification and quantification of prescribing errors in the study sample. We consensed several definitions at the moment of choosing variables in order to categorize prescriptions as appropriate or inappropriate (WHO, 2006; Dean et al., 2000; Cobaugh, Krenzelok, 2006). Dean et al. (2000) developed the following practitioner led consensus definition of a prescribing error for use in quantitative studies of their incidence: "a clinically meaningful prescribing error occurs when, as a result of a prescribing decision or prescription writing process, there is an unintentional significant reduction in the probability of treatment being timely and effective or increase in the risk of harm when compared with generally accepted practice".

According to Dean et al. (2000), some of the situations that should be included as prescribing errors are: prescription of a contraindicated drug, prescription of a drug to which the patient has a documented clinically significant allergy, potentially significant drug interaction, prescribing a drug in a dose that is inappropriate for the patient's condition, prescribing a drug for which there is no indication for that patient, prescribing two drugs for the same indication when only one of the drugs is necessary, continuing a prescription for a longer duration than necessary (depending on the individual clinical situation) and unintentionally not prescribing a drug for a clinical condition for which medication is indicated (depending on the individual clinical situation). On the other hand, situations like prescribing by brand name should be excluded as prescribing errors.

Other definition we took into consideration was that of the Toxic Exposure Surveillance System (TESS) of the American Association of Poison Control Centers, where a "therapeutic error" is defined as "an unintentional deviation from a proper therapeutic regimen that results in the wrong dose, incorrect route of administration, administration to the wrong person, or administration of the wrong medication or product used as medication". Also considered as therapeutic errors in the TESS definition, are the drug-drug and drug-food interactions resulting from unintentional administration either drugs or foods (Cobaugh, Krenzelok, 2006).

WHO established that "the rational use of drugs involves medications available at the lowest possible cost, prescribed to meet patients' individual clinical needs, given in appropriate doses and for adequate period of time" (WHO, 2006). In this way, according to WHO terminology, prescriptions could be classified as "rational" or "irrational", but in order to smooth those terms we used the words "appropriate" or "inappropriate" to categorize prescriptions.

We also explicitly defined the pharmacotherapeutic indicators and their scores used for calculating the benefitrisk ratio for each prescription, since publications where detailed quantitative determination of this ratio and the indicators to calculate it, are hard to find. The 214 prescriptions rated as "inappropriate" had mostly errors on indication and dosage regimen of the prescribed medications, thus being these pharmacotherapeutic variables the determinant indicators chosen for the benefitrisk ratio calculation.

Our study found that NSAIDs and antibiotics were the most-prescribed drugs. This is in accordance with the fact that the respiratory system diseases (ICD: J00-J99), particularly the acute upper and lower respiratory infections, and the injury, poisoning and certain other consequences of external causes (ICD: S00-T99) had the highest reported morbidity rates among our patients. The diseases of the digestive system and the intestinal infections diseases were other frequently found diagnoses. Though, we found a high frequency of inappropriate empirical selection and prescription of antibiotics, demonstrating the need to standardize the drug selection process. For the same diagnosis, several different antibiotics were empirically ordered (and no information about microbiological studies was found in the medical records), also second-line antibiotics or contraindicated antibiotics for the type of presumed infection were prescribed. Many examples were prescriptions for rhinopharyngitis and acute pharyngitis diagnoses, for which 6 and 11 different antibiotics were empirically prescribed, respectively. We think that the reason why general practitioners prescribed many different medications for a single diagnosis at the primary care unit where we did the present study, is because this clinic belongs to the private health sector, and there is no essential medicines list, nor institutional pharmacotherapeutic guidelines limiting or regulating drug selection.

High frequency of nimesulide prescriptions showed us that its use and its adverse reactions in Mexican population need further investigation, since nimesulide has been prohibited or limited in its utilization in several countries, due to the increasing incidence of adverse reactions, particularly hepatotoxicity (Francis, 2002; Mahajan, Sharma, 2005; Paz, 2006).

Only 20 of the 280 different active substances prescribed, were ordered by generic name. We think that this fact may caused prescription errors due to medication duplicity (3.8\%), since prescribing using trade names implicate the risk of duplicate when the physician does not 
exactly know which drug or drug combinations are contained in the medication. Moreover, prescribing tradename drugs implicates a higher probability of confusing Look Alike/Sound Alike drug names, thus prescribing a not indicated medication that could harm the patient.

Five of the ten most prescribed drugs of this study have generic versions available on the Mexican market ("genéricos intercambiables" or bioequivalent drugs) and approved by the Mexican health authorities (ciprofloxacin, ranitidine, oral ketorolac, parenteral ketorolac, amoxicillin and paracetamol). However, Mexican health professionals and patients do not trust enough non-brand name substitutes because of the existence on the market of several pharmaceutical products ("innovators", "bioequivalent drugs", "generics" and "similars") that lead to misunderstanding and confusion. We suppose that for this reason, general practitioners in our study did not use generic names for prescribing and did not even prescribe bioequivalent drugs. We also think that a consequence of this, was the medication duplicity errors found for paracetamol, the seventh most prescribed drug in our study. If physicians did not have enough information about drugs contained in medications and they used to prescribe by brand name, duplicities could appear and patient could be exposed to supratherapeutic doses of certain drugs, as observed in this study for paracetamol.

The duplicity errors that we found in this study, happened mostly with NSAIDs, which is comparable to other findings (Borrás et al., 2005).

Prescriptions with errors on the indication of the drug were frequent (25\%), justifying the inclusion of pharmacists in patient care for advising physicians, validating prescriptions and developing a pharmacotherapeutic guide along with the rest of the health care team.

A mean of 1.9 drugs was prescribed per patient per visit. This was consistent with the low incidence of chronic diseases treated at the studied clinic and most probably due to the predominance of young patients seen at this unit.

Nimesulide, paracetamol, ketorolac and ketoprofen were the drugs most frequently prescribed in combinations of drugs that could lead to drug-drug interactions. The potential risk to the patient could not be assessed and no appropriate action could be taken because of the retrospective nature of this study. One combination of moderate clinical significance was paracetamol and ketoprofen. It has been reported that this combination may increase the nephrotoxic and gastrointestinal adverse effects of both drugs administered alone (Stockley, 2007). This drug-drug interaction was the most frequently observed because of the existence of medications containing both drugs on the Mexican market. These medications are sold in Mexico as OTC-products and they are prescribed and dispensed to patients of all ages. Paracetamol/ketoprofen containing combination products are licensed in Mexico, Uruguay and Paraguay, but not in USA, Spain, United Kingdom, Argentina or Brazil (Vademecum México, 2006).

Combined prescription of drugs with potential hazardous drug-drug interactions reported in literature, should be taken with caution and appropriate monitoring, as well as with enough information for the patient. The latter is particularly important in Mexico, because there are no pharmacists advising patients at community pharmacies, making self-medication an increasing public health problem. Patients could then "copy" the prescription habits of their physicians in their self-medication practices, expanding irrational use of drugs.

Many studies suggest that lack of information about the patient, such as diagnosis, race/ethnicity, age, weight, history of allergies, nicotine and alcohol dependence, drug abuse, renal/hepatic function, previous or concurrent medications and laboratory data, could lead to majority of the reported drug adverse reactions (Otero et al., 1992; Kelly, 2001; Leape et al., 1995). We detected in our study, that important data about the patient's clinical history and actual health condition, like the concomitant drug use and toxic habits of the patients, was missing in the analyzed medical records. This was a limitation for assessing prescriptions but also for detecting unexpected risks of the prescribed pharmacotherapy, since we could not monitor patients neither know if errors on indication or potential interactions reached them. We thus recommended to the primary care clinic the optimization of the medical records.

The prescription errors detected in this study lead us once again to determine the critical role of pharmacists monitoring medication orders and documenting their interventions toward reducing medication errors.

Drug utilization studies are the first efforts in Mexico to identify prescription patterns and medication errors at various levels of health care facilities, in order to position Mexican pharmacists among primary health care providers, to develop best practices in medication safety and increase physicians' awareness about medication errors and how to prevent them.

\section{CONCLUSIONS}

This study revealed a relative high incidence of inappropriate prescriptions in a Mexican primary care university clinic comparable to reported in literature, due to inappropriate dosage regimen and drug selection according to patient's indication. Nimesulide, cipro- 
floxacin, ranitidine, ketorolac and paracetamol were the most prescribed drugs as well as the cause of the majority of prescription errors, according to the pharmacotherapeutic variables assessed. We demonstrated the need of drug prescription validation done by pharmacists and of pharmacotherapeutic guidelines supporting the selection of drugs in primary care. Our study justified the role that Mexican pharmacists should be playing for preventing medication errors as a key part of the health care team, as well as the urgency of pharmaceutical care implementation in all Mexican healthcare levels for ensuring that therapeutic outcomes are achieved.

\section{ACKNOWLEDGEMENTS}

We would like to thank Dr Alfredo Memije Neri, director of the primary care unit where this study was carried out, general practitioners, nurses and administrative staff for help with the data collection.

\section{RESUMO}

\section{Erros de prescrição no Centro de Saúde de uma Universidade: urgência de implementar Atenção Farmacêutica no México}

O objetivo deste trabalho foi avaliar a racionalidade das prescrições como também os erros mais comuns nas prescrições emitidas pelo Centro de Saúde de uma Universidade no México. Foi realizado um estudo retrospectivo de utilização de medicamentos que requeria prescrição médica. 370 expedientes médicos foram aleatoriamente selecionados e revisados, obtendo uma mostra estatísticamente representativa do total de consultas médicas realizadas no periodo de um ano. A validade da prescrição médica foi feita utilizando as seguintes variáveis: indicação, doses recomendada, via de administração, contra-indicações, interações, duplicação de medicamentos, medicamentos desnecessários ou faltantes. As prescrições médicas foram classificadas como: apropriada (se não foram encontrados erros nas prescrições) ou inapropriada (se foram encontradas ao menos um erro na prescrição). A razão risco-beneficio foi calculada para cada prescrição médica. O estudo revelou alta incidência de prescrições inapropriadas no Centro de Saúde da Universidade do México (58\%), causada pelos erros nas doses recomendadas e na seleção do medicamento relacionado com a necessidade do paciente. Como resultado da análise $\chi^{2}$, foi encontrado que as variáveis fármaco-terapêuticas escolhidas neste estudo para avaliar a prescrição médica, foram determinantes para classificar as prescrições como apropriadas. Nimesulide, ciprofloxacin, ranitidine, ketorolac e paracetamol representaram o maior número de medicamentos prescritos assim como a maior causa de erros encontradas nas prescrições. É importante que um farmacêutico valide os medicamentos prescritos no Centro de Saúde. Este estudo justifica o papel que os farmacêuticos mexicanos deveriam desempenhar para evitar erros na prescrição, como parte importante da equipe médica, assim como a urgência de implementar os cuidados farmacêuticos em todos os estabelecimentos dos Centros de Saúde no México.

UNITERMOS: Medicamentos/estudo de utilização. Medicamentos/uso racional. Medicamentos/erros de prescrição. Atenção farmacêutica.

\section{REFERENCES}

AMERICAN SOCIETY OF HEALTH-SYSTEM PHARMACISTS. ASHP guidelines on preventing medication errors in hospitals. Am. J. Hosp. Pharm., Bethesda, v. 50, p.305-314, 1993.

BAKKER, A. Pharmacy-practice research: A challenge for academia and practicing pharmacists. Pharm. Acta Helv., Netherlands, v.71, p.373-379, 1996.

BORRÁS, S. et al. Análisis de los riesgos detectados en la dispensación activa de antigripales/anticatarrales. In: CONGRESO NACIONAL DE ATENCIÓN FARMACÉUTICA, 4., 2005, Valencia, España. Disponível em: <www.redfarmaceutica.com/atencion/ carteles04/06.pdf>. Acesso em: 07 May 2006.

COBAUGH, D. J.; KRENZELOK, E. P. Adverse drug reactions and therapeutic errors in older adults: A hazard factor analysis of poison center data. Am. J. Health Syst. Pharm., Bethesda, v.63, p.2228-34, 2006.

DEAN, B.; BARBER, N.; SCHACHTER, M. What is a prescribing error? Qual. Health Care, London, v.9, p.232237,2000 .

DIPIRO, J.; TALBERT, R.; YEE, G.; MATZKE, G.; WELLS, B.; POSEY, M. Pharmacotherapy: A Pathophysiologic Approach. 6.ed. New York: Mc Graw Hill, 2005. 2802 p. 
FIGUEIRAS, A.; CAAMAÑO, F.; GESTAL-OTERO, J. J. Metodología de los estudios de utilización de medicamentos en atención primaria. Gac. Sanit., Barcelona, v.14, suppl.3, p.7-19, 2000.

FRANCIS, P.A. Nimesulide Review Now? Editorial Octubre 2002. Disponível em: <http://www.pharmabiz.com/ article/detnews.asp? articleid $=12422 \&$ sectionid $=47>$ Acesso em: 30 apr. 2006.

GENERALITAT DE CATALUNYA, Departament de Salut. Boletín de prevención de los errores de medicación de Cataluña. In: JORNADA MONOGRÁFICA: SEGURIDAD DELPACIENTEY MEDICAMENTOS. Academia de Ciencias Médicas y de la Salud de Cataluña y de Baleares. Salut, v.1, p.1-10, 2004.

GONZÁLEZ, B.; LÓPEZ, A.; CABEZA, A.; DÍAZ, J.A.; ORTÚN, V.; ÁLAMO, F. Estudios de Utilización de Medicamentos y registros de datos en Atención Primaria. España: Universidad de las Palmas Gran Canaria, 2005. Disponível em: $<$ http://www.recercat.net/bitstream/2072/ 953/1/809.pdf > . Acesso em: 25 mar. 2007.

GONZÁLEZ, Juan Miguel; VISO, Fela. Estudio de utilización de antibióticos en un hospital pediátrico mexicano. Rev. O.F.I.L., v.11, p.58-64, 2001.

HERNÁNDEZ, M.; GARRIDO-LATORRE, F.; LÓPEZMORENO, S. Diseño de estudios epidemiológicos. Salud Publica Mex., Mexico, v.42, n. 2 p.144-154, 2000.

KELLY, William N. Potential risks and prevention, part 1: Fatal adverse drug events. Am. J. Health Syst. Pharm., Bethesda, v.58, n. 14, p.1317-1324, 2001.

LEAPE, L.L. ; BATES, D.W. ; CULLEN, D.J.; COOPER, J.; DEMONACO, H.J.; GALLIVAN, T.; HALLISEY, R.; IVES, J.; LAIRD, N.; LAFFEL, G.; NEMESKAL, R.; PETERSEN, L.A.; PORTER, K.; SERVI, D.; SHEA, B.; SMALL, S.; SWEITZER, B.J.; THOMPSON, B.T. Systems analysis of adverse drug events. JAMA, Chicago, v.274, n. 1, p.35-43, 1995.

LÓPEZ-SÁNCHEZ, E. P.; FÉLIX-RODRÍGUEZ, K. M.; REYES, I.; VISO-GUROVICH, F. Farmacovigilancia en Pediatría. Arch. Inv. Ped. Mex., Mexico, v.4, p.441-450, 2001.
LYLE, C. B.; WERTHEIMER, A. I.; ZASKE, D.; ROBBLAN, C. Individualized gentamicin dosage regimens in burn patients with gram-negative septicemia: A cost-benefit analysis. J. Pharm. Sci., Lawrence, v.68, p.267-272, 1979.

MAHAJAN, A.; SHARMA, R. COX-2 selective nonesteroidal antiinflamatory drugs: current status. $J$. Assoc. Physicians India, Mumbai, v.53, p.200-204, 2005.

MARCELLINO, Kimberly.; KELLY, William N. Potential risks and prevention, part 3: Drug-induced threats to life. Am. J. Health Syst. Pharm., Bethesda, v.58, p.1399-1405, 2001.

McEVOY, Gerald K., (Coord.) AHFS Drug Information. Bethesda: American Society of Health-System Pharmacists (ASHP), 2006. 3776 p.

McEVOY, Gerald K., (Coord.) Drug Information ESSENTIALS 2005-2006. 6. ed. Bethesda, MD: American Society of Health-System Pharmacists (ASHP), 2006. 2265 p.

MONTAÑO, C.; VISO, Fela. Evaluación del funcionamiento del primer Centro de Información de Medicamentos en México. Rev. O.F.I.L., v.1, p.47-53, 2000.

NATIONAL COORDINATING COUNCIL FOR MEDICATION ERROR REPORTING AND PREVENTION. NCCMERP Taxonomy of medication errors. Disponível em: <http://www.nccmerp.org/ aboutMedErrors.html> Acesso em: 25 mar. 2007.

ORGANIZACIÓN PANAMERICANA DE LA SALUD. Buenas Prácticas de Farmacia. Informe de la reunión de la OMS, OPS/OMS: Japan, 1993. Disponível em: <http:/ /www.opas.org.br/medicamentos/site/uploadarq/ops-hsshse-95-01.pdf $>$. Acesso em: 25 mar. 2007.

ORGANIZACIÓN PANAMERICANADE LA SALUD. $E l$ papel del farmacéutico en el Sistema de Atención de Salud. Informe de la Reunión de la OMS. OPS/HSS/ HSE/95.01 (WHO/PHARM/94.569). Tokyo: OPS/ OMS, $1993.35 \mathrm{p}$. 
OTERO, M. J.; MARTÍN, R.; ROBLES, M. D.; CODINA, C. Errores de Medicación. In: BONAL, J.; DOMÍNGUEZ-GIL, A.; GAMUNDI, M.; NAPAL, V.; VALVERDE, E. Farmacia Hospitalaria. Madrid: Sociedad Española de Farmacia Hospitalaria, 1992. p. $713-747$

PAZ, R. MSDS ordena retirar del mercado medicamentos pediátricos a base de Nimesulide. Ministerio de Salud, Gobierno Bolivariano de Venezuela. Disponível em: $<\mathrm{ht} \mathrm{tp}$ :// w w w.m s d s.gov. ve/m sd s/ modules.php? name $=$ News $\&$ file $=$ article $\&$ sid $=170>$. Acesso em: 30 apr. 2006.

RAMOS, L.; ALVAREZ, R. M.; MARTÍNEZ, Y.; MEDINA, A. Beneficio/riesgo de la prescripción de nifedipino en la atención primaria de salud. MEDISAN, Cuba, v.7, n. 3, p.27-32, 2003.

RANDALL, M. D.; NEIL, K. E. Disease Management. United Kingdom: Pharmaceutical Press, 2004. 492 p.

SECRETARÍA DE SALUD DE MÉXICO. Hacia una política farmacéutica integral para México. 1.ed. México: SSA, 2005. p.104.
STOCKLEY, I. Drug Interactions. London: Pharmaceutical Press, 2007. In: MEDICINES COMPLETE. Disponível em: $<$ www.medicinescomplete.com $>$. Acesso em: 25 mar. 2007.

TAMBLYN, R.; Mc LEOD, M. D.; HANLEY, J. A.; GIRARD, N.; HURLEY, J. Physician and Practice Characteristics Associated with the Early Utilization of New Prescription Drugs. Med. Care, Washington, v.41, p.895-908, 2003.

VADEMÉCUM MEXICO. Disponível em: < http:// www.prvademecum.com/default.asp $>$. Acesso em: 25 mar. 2007.

VISO, F.; GÓMEZ, L.; GONZÁLEZ, M. Evaluación de la utilización de cloranfenicol en el servicio de lactantes de un hospital pediátrico mexicano. Pharm. Care Esp., Barcelona, v.5, p.182-185, 2003.

WORLD HEALTH ORGANIZATION. Uso racional de los medicamentos: progresos realizados en la aplicación de la estrategia farmacéutica de la OMS. Switzerland Geneva: WHO, 2006. 7 p.

Recebido para publicação em 28 de maio de 2007. Aceito para publicação em 21 de agosto de 2007. 